\title{
The Indian Demand for Imported Fresh Apples: Effects of Tariff Reductions
}

\author{
Kwanyoung Lee ${ }^{1}$, R. Karina Gallardo ${ }^{2, \star}$ (1) and Miguel Giacinti ${ }^{3}$ \\ ${ }^{1}$ School of Economic Sciences, Washington State University, Pullman, Washington, USA, ${ }^{2}$ School of Economic Sciences, \\ Puyallup Research and Extension Center, IMPACT Center, Washington State University, Puyallup, Washington, USA \\ and ${ }^{3}$ Fruit and Vegetable Information Center, CIF Business, Centenario, Neuquen, Argentina \\ ${ }^{\star}$ Corresponding author. Email: karina_gallardo@wsu.edu
}

\begin{abstract}
We estimated the impact of the Indian tariff on the demand for imported fresh apples from theUnited States. A $1 \%$ decrease in the tariff would increase the quantities demanded by $3.83 \%$. If India eliminates the tariff on all imported fresh apples, total consumer welfare in terms of the imported fresh apple market will increase by $\$ 120$ million yearly, $57 \%$ of the value of all fresh apples imported by India in 2015 . This study adds evidence on the effects of tariff reduction on trade volume and welfare of consumers in the importing country.
\end{abstract}

Keywords: AIDS model; export markets; source differentiation; tariff

JEL Classification: Q17

\section{Introduction}

India is a promising market for the expanding exports of major fresh fruit producing countries, including the United States. The Indian economy has grown since the economic reform process began in the early 1990s (Ahluwalia, 2002), from a per capita gross national income of $\$ 380$ (in current U.S. dollars) in 1990 to \$2,020 in 2018 (The World Bank, 2019). One consequence of this economic growth is the expansion of fresh fruit imports, particularly apples, from around the world. In 1990, India imported no fresh apples, but in 2017 fresh apple imports reached 204,000 tons (United Nations, 2018). This general increase has been mirrored in Indian imports from the United States, from 440 tons of fresh apples, valued at $\$ 303,000$ in 2000 to 164,000 tons in 2018, valued at $\$ 164.5$ million (United Nations, 2018). This increase was despite the existing $50 \%$ tariff imposed by India on U.S. fresh apples. Moreover, effective June 2019, India imposed an additional 20\% tariff on the same goods (Northwest Horticultural Council, 2019). Mishra (2013) argues that U.S. imported apples enjoy a differentiated market position because of their perceived higher quality compared with domestically produced apples or imported apples from other countries, such as China.

Despite the increase in imports, Indian consumption of fresh apples is still far below the world average: In 2013, annual per capita consumption of all apple products was $1.52 \mathrm{~kg}$, compared with a world average of $10 \mathrm{~kg}$ (Food and Agriculture Organization of the United Nations, 2018), but it is increasing at the rate of $4.2 \%$ annually (Index Mundi, 2018; The World Bank, 2018). Clearly, there is potential for increasing demand for apples in India.

The Indian government has entered into several relevant free trade agreements (FTAs) over the years (India Department of Commerce, Ministry of Commerce and Industry, 2018). Within Asia,

(C) The Author(s) 2019. This is an Open Access article, distributed under the terms of the Creative Commons Attribution licence (http:// creativecommons.org/licenses/by/4.0/), which permits unrestricted re-use, distribution, and reproduction in any medium, provided the original work is properly cited. 
India has signed bilateral FTAs with nine countries, including Sri Lanka (1998), Afghanistan (2003), Thailand (2004), Singapore (2005), Bhutan (2006), Nepal (2009), South Korea (2009), Malaysia (2011), and Japan (2011) (India Department of Commerce, Ministry of Commerce and Industry, 2018). In addition, India is part of several regional trade agreements, including the South Asian Free Trade Agreement (SAFTA in 2004); the Association of Southeast Asian Nations Agreement (ASEAN in 2010); the Asia-Pacific Trade Agreement (APTA in 1975) to which China acceded in 2001; and the India-Africa Trade Agreement among India and 19 African countries including South Africa (India Department of Commerce, Ministry of Commerce and Industry, 2018). Moreover, India has preferential trade agreements with Chile (2006) and Mercosur, a South American trade bloc (2004). In 2016, the governments of India and New Zealand launched a commitment to continue working toward a comprehensive bilateral trade agreement (New Zealand, Foreign Affairs and Trade, 2018). Despite, India's increased interested in FTAs, there has been no agreement with the United States.

This article measures the impact of the $50 \%$ tariff imposed by India on the quantities demanded of imported fresh apples and quantifies the resulting welfare changes among Indian consumers. We use a restricted source-differentiated almost ideal demand system (RSDAIDS) model to measure the effect of the tariff levy on U.S. exports of fresh apples to India and include major U.S. competitors-such as China and Chile-in the Indian market. To illustrate substitution effects among fresh fruit imports, we include imports of fresh pears, grapes, and other fresh fruits in the model but retain our focus on Indian fresh apple imports. In addition, we use the compensating variation technique to estimate the effect of tariffs on Indian consumer welfare.

Fresh apples are one of the most valuable fruits in the United States, with a direct sale value equivalent to \$3.013 billion in 2018 (U.S. Department of Agriculture, Economic Research Service, 2019). The U.S. apple industry has consolidated in the last 20 years. Low apple prices in the late 1990s and early 2000s forced a considerable number of fresh apple operations out of business. High-density production systems and other technologies are now the norm for apple plantings. These systems require considerable initial investment and have higher maintenance costs, contributing to industry consolidation (U.S. International Trade Commission, 2010). U.S. demand for domestic fresh apples has stagnated in the last decade: Per capita consumption was at 7.43 $\mathrm{kg}$ in $2007 / 2008$ and increased by $8 \%$ to $8.02 \mathrm{~kg}$ in $2017 / 2018$ (U.S. Department of Agriculture, Economic Research Service, 2019). Given the increase in domestic production volume and the challenge of stagnant consumption, maintaining and expanding market share in export markets, including India, is considered critical for the survival of the U.S. apple industry (Ferreira and Perez, 2016; Luckstead, Devadoss, and Mittelhammer, 2014). This study includes an assessment of the impacts of a potential increase in the demand for imported U.S. fresh apples in India because of tariff elimination.

\section{Literature review}

Abundant literature suggests that tariff reduction increases both international trade volume and countries' welfare. Using partial equilibrium models to assess international trade of agricultural goods, Ananthramiah (1996) estimated the effects of the North American Free Trade Agreement (NAFTA) on beef trade among the United States, Canada, and Mexico and found that the agreement effects would be realized in the long run and that Mexican beef exporters would benefit most from the agreement. Durand-Morat and Wailes (2005) studied the potential effects of CAFTA (Central America Free Trade Agreement) on the rice industry in signatory countries using both general and partial equilibrium models. They found that the largest welfare benefits would be accrued by the United States compared with Central American rice producers. Naanwaab and Yeboah (2012) studied the effect of NAFTA on a number of commodities, including corn, soybeans, cotton, wheat, fresh vegetables, poultry, dairy, and red meats. They used a partial 
equilibrium framework and found mixed evidence. Trade volume increased for some commodities, such as Mexican exports of tomatoes to the United States. However, trade volume decreased for some other commodities, such as U.S. exports of corn and poultry to Canada. Considering the net effects, trade volume increased among the three countries.

A number of studies have focused on the impact of tariffs on the fresh apple trade. Devadoss and Ridley (2014) studied the impacts of Mexican tariffs imposed on U.S. apples and found that the overall welfare impact is negative because consumer losses outweigh producer gains and tariff revenues. Zahniser, Hertz, and Argoti (2016) found that retaliatory import tariffs imposed by Mexico on selected U.S. agricultural products reduced U.S. sales to Mexico by $\$ 923$ million during the period in which the retaliatory tariffs were in effect; fresh apples lost $\$ 119$ million, one of the four agricultural goods with the largest loss in sales to Mexico because of the tariffs.

In relation to the Indian fresh apple import market, Devadoss and Wahl (2004) studied the impacts of Indian trade policies on apple imports and found that, under free trade, India's fresh apple consumption would increase by $12 \%$. They also estimated that a $30 \%$ increase in fresh apple imports would be expected under free trade and that eliminating tariffs would increase total consumer and producer welfare in India. In a similar study, Devadoss, Sridharan, and Wahl (2009) found that the volume of apples traded between the United States and the rest of the world could increase significantly with the removal of tariffs and showed that India and Southeast Asia could be potential markets for U.S. apple exports. Because those countries have high tariffs-ranging from $45 \%$ to $61 \%$-decreasing consumer prices by tariff removal would lead to an increase in demand for fresh apples.

Because China is a major U.S. competitor in the fresh apple export market, Luckstead, Devadoss, and Mittelhammer (2014) analyzed the apple export competition between the United States and China in the ASEAN countries. They developed a trade model under imperfect competition and found that eliminating Chinese tariffs would contract U.S. exports to ASEAN countries, but complete free trade would favor U.S. apple producers, as U.S. apple exports would displace Chinese apple exports.

The overall findings in the literature reveal that eliminating tariffs in the Indian fresh apple market would increase trade volume and consumer welfare in the importing country. Our study has a similar aim and scope as that of Devadoss and Wahl (2004). However, our study considers substitutability among major (by volume) fruits in the Indian import market. Estimating demand for fruits individually, without considering the prices of other fruits, may lead to incorrect results. We use the RSDAIDS model to observe quality differentiation among apples imported from different countries. In addition, we use a compensating variation technique to estimate the impact of India's tariff on demand for imported fresh apples and consumer welfare in India.

\section{Empirical framework}

This study constructs an import demand model following Deaton and Muellbauer's (1980) almost ideal demand system (AIDS). We depart from AIDS to use the source-differentiated AIDS model suggested by Yang and Koo (1994), which aims to model importer behavior that differentiates goods based on their origins. We consider this model to more closely approximate to our research problem because fresh apples could be differentiated according to the country from which they are imported. However, the source-differentiated AIDS model may suffer from a degrees-of-freedom problem in empirical applications, as mentioned in Yang and Koo (1994). Fresh fruits usually have several substitutes from different import origins, causing the model to have too many parameters in each equation. To reduce the number of parameters, we use the RSDAIDS (restricted sourcedifferentiated almost ideal demand system) model derived by Yang and Koo (1994). The RSDAIDS model introduces a block substitutability assumption to fix the degrees-of-freedom problem. For example, fresh apples imported from the United States could be substituted by pears 
imported from any other country. With this assumption, the expenditure share equation is as follows:

$$
w_{i_{h}}=\alpha_{i_{h}}+\sum_{k} \gamma_{i_{h k}} \ln \left(p_{i_{k}}\right)+\sum_{j \neq k} \gamma_{i_{h} j} \ln \left(p_{j}\right)+\beta_{i_{h}} \ln \left(\frac{E}{P}\right)
$$

where $w_{i_{h}}$ is the expenditure share of fruit $i$ from country $h$ among all imported fruits; $\alpha_{i_{h}}$ represents the estimated budget share of fruit $i$ from country $h$ when all logarithmic prices and real expenditures are $0 ; \beta_{i_{h}}$ is the expenditure coefficient and represents the change in the expenditure share of fruit $i$ from country $h$ with respect to change in real income; and $\gamma_{i_{h} j}$ represents the change in the budget share of commodity $i$ from country $h$ with respect to a percentage change in the price of fruit $j$, with real expenditures held constant. Subscripts $i$ and $j$ denote fruits $(i, j=1, \ldots, N)$, and $i$ and $j$ are substitutable; $h$ and $k$ denote country of origin. Each fruit can have a different number of countries of origin. For example, fruit $i$ may be imported from $m$ different countries, whereas fruit $j$ may be imported from $n$ countries. $p_{i_{k}}$ denotes the price of fruit $i$ imported from country $k$; $p_{j}$ denotes the price of fruit $j . E$ denotes total expenditures in all goods in this demand system, and $P$ is the Stone's price index $\ln P=\sum_{i} \sum_{h} w_{i_{h}} \ln p_{i_{h}}$ to come up with a linear approximation (Deaton and Muellbauer, 1980). To avoid singularity effects, the share equation for other imported fruits is dropped from the system of equations. Further, we tested the adding-up condition following Barten (1969) who stated that the estimation results should not be affected if one of the equations in the system of equations is dropped.

The Marshallian price elasticities of the RSDAIDS model are the following:

$$
\begin{gathered}
\varepsilon_{i_{h} i_{h}}=-1+\frac{\gamma_{i_{h h}}}{w_{i_{h}}}-\beta_{i_{h}}, \\
\varepsilon_{i_{h} i_{k}}=\frac{\gamma_{i_{h k}}}{w_{i_{h}}}-\beta_{i_{h}}\left(\frac{w_{i_{k}}}{w_{i_{h}}}\right), \\
\varepsilon_{i_{h} j}=\frac{\gamma_{i_{h} j}}{w_{i_{h}}}-\beta_{i_{h}}\left(\frac{w_{j}}{w_{i_{h}}}\right), \\
\varepsilon_{i_{h}}=1+\frac{\beta_{i_{h}}}{w_{i_{h}}} .
\end{gathered}
$$

Equation (2) represents own-price elasticities, equation (3) represents cross-price elasticities between the same goods from different sources, and equation (4) represents cross-price elasticities between different goods (i.e., the cross-price elasticity between fruit $i$ imported from country $h$ and fruit $j$ imported from the rest of the world). $w_{j}$ is the expenditure share of fruit $j$. Equation (5) represents expenditure elasticities of fruit $i$ from country $h$. The general demand conditions are imposed, which are adding-up, homogeneity, and symmetry conditions as following Yang and Koo (1994). Appendix C includes further details of the derivations of equations (2)-(5).

This study assumes separability between domestic and imported fruits, an assumption that is usually imposed on import demand estimations (see studies by Alston et al., 1990; Seale, Sparks, and Buxton, 1992; Weatherspoon and Seale, 1995). Our separability assumption is further justified by the fact that the Indian domestic and imported fresh fruit markets can be considered separate markets given the tariffs imposed by India on imported fresh fruits, making imported fruit more expensive than domestic fruit; India imposes a 50\% tariff on all imported fresh apples and a $30 \%$ tariff on all pears and grapes. 
Table 1. Test results of block separability and product aggregation: RSDAIDS (restricted source-differentiated almost ideal demand system) model of Indian fresh apple imports

\begin{tabular}{|c|c|}
\hline Test for Block Separa & \\
\hline \multicolumn{2}{|c|}{$\mathrm{H}_{0}$ : Apple is separable from all other fruits. } \\
\hline $\mathrm{LR}=123.15^{\star \star}$ & $\mathrm{df}=12$ \\
\hline \multicolumn{2}{|c|}{$\mathrm{H}_{0}$ : Pear is separable from all other fruits. } \\
\hline $\mathrm{LR}=154.40^{\star \star}$ & $\mathrm{df}=12$ \\
\hline \multicolumn{2}{|c|}{$\mathrm{H}_{0}$ : Grape is separable from all other fruits. } \\
\hline $\mathrm{LR}=78.27^{\star \star}$ & $\mathrm{df}=9$ \\
\hline \multicolumn{2}{|c|}{$\mathrm{H}_{0}$ : All of the above (apple, pear, grape). } \\
\hline $\mathrm{LR}=197.90^{\star \star}$ & $\mathrm{df}=33$ \\
\hline \multicolumn{2}{|c|}{ Test for Product Aggregation } \\
\hline \multicolumn{2}{|c|}{$\mathrm{H}_{0}$ : Apple can be aggregated. } \\
\hline$\chi^{2}=3,966.78^{\star \star}$ & $\mathrm{df}=18$ \\
\hline \multicolumn{2}{|c|}{$\mathrm{H}_{0}:$ Pear can be aggregated. } \\
\hline$\chi^{2}=28,946^{\star \star}$ & $\mathrm{df}=18$ \\
\hline \multicolumn{2}{|c|}{$\mathrm{H}_{0}$ : Grape can be aggregated. } \\
\hline$\chi^{2}=3,342^{\star *}$ & $\mathrm{df}=12$ \\
\hline \multicolumn{2}{|l|}{$\mathrm{H}_{0}$ : All of the above. } \\
\hline$\chi^{2}=92,706.12^{\star \star}$ & $\mathrm{df}=48$ \\
\hline
\end{tabular}

\subsection{Test for block separability}

Block separability allows each type of fruit to be estimated individually without having to consider the prices of other fruits. Hayes, Wahl, and Williams (1990) derive the restriction that is implied by the quasi-separability of the cost function. We chose this approach because the AIDS model is based on a flexible functional form of the cost function. The null hypothesis for the block separability test is that each fruit variety is separable from all other fruits: $\gamma_{i_{h} j}=w_{i_{h}} \gamma_{i j} \forall j \neq h$, where $\gamma_{i_{h} j}$ is the cross-price parameter between fruit $i$ imported from country $h$ and fruit $j$, estimated from RSDAIDS; $w_{i_{h}}$ is the expenditure share on fruit $i$ imported from country $h$; and $\gamma_{i j}$ is the cross-price parameter between fruit $i$ and fruit $j$ estimated from an aggregated AIDS model that is not differentiated by sources. The log-likelihood ratio test results for block separability reject the hypothesis that apple, pear, grape, and other fruits are separable from one another at the $1 \%$ significance level (see Table 1). Therefore, studying each fruit separately is not an appropriate assumption for the Indian imported apple market, supporting the use of a source-differentiated model.

\subsection{Test of product aggregation}

We use the product aggregation test to prove that consumers place different values on the same fruit from different countries. In other words, fruit imports have been disaggregated by origin because fruit prices are not homogeneous and quality attributes of fruits related to origin may influence consumer choices. To test product aggregation, we compare three parameters estimated 
from the AIDS model $\left(\alpha_{i}, \gamma_{i j}, \beta_{i}\right)$ and from the RSDAIDS model $\left(\alpha_{i_{h}}, \gamma_{i_{h} j}\right.$, and $\left.\beta_{i_{h}}\right)$. The null hypothesis is that each fruit can be aggregated across sources $\left(\alpha_{i_{h}}=\alpha_{i} ; \gamma_{i_{h} j}=\gamma_{i j} ; \beta_{i_{h}}=\beta_{i}\right)$, where $\alpha_{i_{h}}$ is the intercept estimated by RSDAIDS and $\alpha_{i}$ is estimated by AIDS, $\gamma_{i_{h} j}$ is the cross-price estimate between fruit $i$ from country $h$ and fruit $j$ estimated from RSDAIDS, $\gamma_{i j}$ is the estimate between fruits $i$ and $j$ estimated from AIDS, $\beta_{i_{h}}$ is the expenditure coefficient and represents the change in the expenditure share of fruit $i$ from $h$ with respect to change in real income from RSDAIDS, and $\beta_{i}$ is the expenditure coefficient of fruit $i$ from AIDS. Wald test results reject the null hypothesis that each fruit can be aggregated at the $1 \%$ statistically significant level (see Table 1). In addition, we conducted tests for heteroscedasticity (Breusch-Pagan test) and autocorrelation (Breusch-Godfrey Lagrange Multiplier test) and found no evidence of heteroscedasticity or autocorrelation in the model.

\subsection{Test of price and expenditure endogeneity}

Demand estimation models do not control for possible price and expenditure endogeneity, which might lead to biased parameter estimates (Dhar, Chavas, and Gould, 2003). We use a Durbin-Wu-Hausman (DWH) test. Following Henneberry and Hwang (2007) and Andayani and Tilley (1997), we use the consumer price index of the exporting country and lagged real expenditure as instrumental variables to test price and expenditure endogeneity. The null hypothesis is that $\theta_{S U R}$ is consistent. We perform the DWH test, in which the $\theta_{S U R}$ is from the RSDAIDS model and $\theta_{3 S L S}$ is from the same RSDAIDS model, treating prices and expenditures as endogenous. We use the consumer price index (CPI) to test price endogeneity and lagged real expenditure to test expenditure endogeneity. Because the CPI and lagged real expenditure have been used in the literature, we select these two instrumental variables to perform the DWH test from among other possible instrument variables that we collected, such as overall fruit exports, precipitation amounts, temperatures, apple growing acreage, number of agricultural workers, input price index, and overall apple production.

The result of the DWH test for expenditure endogeneity is that the null hypothesis cannot be rejected in the case of controlling expenditure as exogenous $\left(\chi^{2}=-71.03\right)$, which indicates that the estimates without controlling for expenditure endogeneity are consistent. We also test price endogeneity, and the $\chi^{2}$ statistics are negative except for price of Chinese pears, which might be interpreted as strong evidence that we cannot reject the null hypothesis. Such a negative result is not an unusual outcome for the DWH test, particularly when the sample is relatively small; our study includes only 16 years of data. In other words, the estimates without controlling for price endogeneity are consistent, excluding the price of Chinese pear.

\subsection{India fresh apple welfare and demand change estimation}

We apply the compensating variation (CV) technique developed by Friedman and Levinsohn (2002). First, they use the minimum expenditure function, which determines the minimum cost needed to attain a certain utility level at given prices. Then we calculate the first-order Taylor expansion of the minimum expenditure function with respect to price, which will yield an approximation of the income required to compensate the household after a price change and to restore that household to the prechange utility level. This first-order Taylor expansion approximates the compensating variation:

$$
\Delta \ln c \approx \sum_{h} w_{i_{h}} \Delta \ln p_{i_{h}}
$$

where $c$ is consumption, $w_{i_{h}}$ is the budget share on fruit $i$ from country $h$ in the initial period, and $p_{i_{h}}$ is the price of the product. Equation (6) captures the direct effect of price change on consumption. However, consumers can substitute one good for another when price changes. 
Thus, we apply the second-order Taylor expansion to account for the substitution effect in the CV computation:

$$
\Delta \ln c \approx \sum_{h} w_{i_{h}} \Delta \ln p_{i_{h}}+\frac{1}{2} \sum_{h} \sum_{k} w_{i_{h}} \varepsilon_{i_{h} i_{k}} \Delta \ln p_{i_{h}} \Delta \ln p_{i_{k}},
$$

where $\Delta \ln p_{i_{h}}$ is the proportionate change in the price of fruit $\mathrm{i}$ from country $\mathrm{h}$, and $\varepsilon_{i_{h} i_{k}}$ is the compensated price elasticity of fruit i from country $h$ with respect to a price change of fruit $i$ from country k. Appendix C explains the derivation of the CV in detail.

\section{Data}

Data on Indian imported fresh fruits were collected from UN Comtrade (United Nations, 2018). Indian fresh fruit imports were divided into four major categories: apple, pear, grape, and other fresh fruits. Because of limitations accessing Indian import data, we included only the three major (by volume) imported fresh fruits. On average for the years 2000-2015, 79.2\% of all Indian fresh fruit imports were apples, 6.3\% were pears, and 4.5\% were grapes (United Nations, 2018). Other fresh fruit imports were contained in the "other fruits" variable, and the equation for other fruits was dropped to avoid singularity because of the adding-up condition (Table 2).

Each fresh fruit type is imported from different countries. We identify a country as a fresh fruit exporting country if it exports at least $10 \%$ of the total fruit imported by India.

Major import sources for apples include the United States, China, and Chile. On average for the years 2000-2015, the United States was the largest (by volume) fresh fruit exporting country to India, accounting for $35 \%$ of all Indian fresh apple imports (25\% came from China). For fresh pears, $50 \%$ of all Indian imports come from China, 22\% from the United States, $19 \%$ from South Africa, and 10\% from other countries. Major import sources for grapes are the United States (56\% of imports) and Australia (18\% of imports) (United Nations, 2018).

\section{Results}

\subsection{India fresh apple conditional demand elasticities}

Table 3 presents the full matrix of Marshallian conditional demand elasticities from the RSDAIDS model. Expenditures on Chinese and U.S. apples are conditionally elastic (1.28 and 1.19, respectively) and more than double those for Chilean apples (0.55). This finding implies that India imports $1.28 \%$ more from China, $1.19 \%$ more from the United States, and $0.55 \%$ more from Chile for each additional $1 \%$ increase in total apple imports. U.S. exports to India consist mostly of 'Red Delicious' apples, while Chilean exports are mostly 'Gala' and 'Red Delicious'; both countries export apples mostly from April to July (Giacinti, 2016). Thus, this finding implies that Indian consumers prefer U.S. 'Red Delicious' apples over Chilean 'Gala' and 'Red Delicious' apples.

Each additional $1 \%$ increase in total imported fresh pears leads to India importing $1.54 \%$ more fresh pears from South Africa, 1.48\% more from the United States, and $0.87 \%$ more from China. For Indian grape imports, each additional $1 \%$ increase in total grape imports leads to India importing $0.86 \%$ more from the United States and $0.02 \%$ more from Australia. This inelasticity indicates that fresh grapes are less affected by changes in import market size (Table 3 ).

Most own-price elasticities for the set of fruits and countries included in this study are negative. Own-price elasticities for apples are conditionally price elastic compared with those for other fruits: -3.96 for imported Chinese apples and -3.38 for imported U.S. apples. The own-price elasticity for pears imported from China $(-1.87)$ is more elastic than that for S. African imported pears $(-1.45)$ and U.S. imported pears $(-0.92)$. Grapes imported from the United States are conditionally price elastic (1.26), grapes imported from Australia are also elastic ( -1.59$)$, and for the rest of the world is price inelastic $(-0.65)$ (Table 3$)$. 
Table 2. Summary statistics for expenditure share and price of Indian fresh fruit imports, 2000-2015

\begin{tabular}{|c|c|c|c|c|}
\hline Variable & Mean & $\begin{array}{l}\text { Standard } \\
\text { Deviation }\end{array}$ & Minimum & Maximum \\
\hline \multicolumn{5}{|l|}{ Expenditure share } \\
\hline Apple & 0.792 & 0.067 & 0.699 & 0.972 \\
\hline United States & 0.281 & 0.086 & 0.089 & 0.408 \\
\hline China & 0.195 & 0.101 & 0.017 & 0.362 \\
\hline Chile & 0.090 & 0.070 & 0.000 & 0.220 \\
\hline Other source & 0.227 & 0.220 & 0.064 & 0.866 \\
\hline Pear & 0.063 & 0.016 & 0.024 & 0.087 \\
\hline China & 0.031 & 0.011 & 0.004 & 0.05 \\
\hline United States & 0.014 & 0.007 & 0.001 & 0.027 \\
\hline South Africa & 0.012 & 0.005 & 0.002 & 0.021 \\
\hline Other source & 0.006 & 0.005 & 0.000 & 0.017 \\
\hline Grape & 0.045 & 0.020 & 0.004 & 0.078 \\
\hline United States & 0.025 & 0.015 & 0.000 & 0.051 \\
\hline Australia & 0.008 & 0.006 & 0.000 & 0.021 \\
\hline Other source & 0.011 & 0.005 & 0.004 & 0.020 \\
\hline Other fresh fruits & 0.100 & 0.040 & 0.000 & 0.188 \\
\hline \multicolumn{5}{|l|}{ Price } \\
\hline \multicolumn{5}{|l|}{ Apple } \\
\hline United States & 0.906 & 0.258 & 0.555 & 1.313 \\
\hline China & 0.788 & 0.195 & 0.551 & 1.085 \\
\hline Chile & 0.878 & 0.202 & 0.559 & 1.117 \\
\hline Other source & 0.945 & 0.212 & 0.635 & 1.173 \\
\hline \multicolumn{5}{|l|}{ Pear } \\
\hline China & 0.506 & 0.125 & 0.341 & 0.767 \\
\hline United States & 1.023 & 0.396 & 0.401 & 1.591 \\
\hline South Africa & 0.848 & 0.302 & 0.376 & 1.192 \\
\hline Other source & 0.958 & 0.561 & 0.434 & 2.641 \\
\hline \multicolumn{5}{|l|}{ Grape } \\
\hline United States & 1.830 & 0.661 & 0.826 & 2.743 \\
\hline Australia & 1.760 & 0.682 & 0.856 & 2.631 \\
\hline Other source & 1.582 & 0.664 & 0.743 & 3.423 \\
\hline Other fresh fruits & 2.536 & 1.304 & 1.515 & 6.824 \\
\hline
\end{tabular}

Table 3 also shows conditional cross-price elasticities. Conditional cross-price elasticities between the United States and Chilean apples are not statistically significant; this may reflect the fact that apples from these two countries are not substitutes. Conditional cross-price elasticities between China and Chile also are not statistically significant, possibly because China mainly 
Table 3. Marshallian elasticities: RSDAIDS (restricted source-differentiated almost ideal demand system) model of Indian fresh apple imports

\begin{tabular}{|c|c|c|c|c|c|c|c|c|c|c|c|}
\hline \multirow[b]{2}{*}{ Price } & \multicolumn{4}{|c|}{ Apple } & \multicolumn{4}{|c|}{ Pear } & \multicolumn{3}{|c|}{ Grape } \\
\hline & United States & China & Chile & ROW & China & United States & South Africa & ROW & United States & Australia & ROW \\
\hline \multicolumn{12}{|l|}{ Apple } \\
\hline \multirow[t]{2}{*}{ United States } & $-3.38^{\star \star}$ & $1.66^{\star *}$ & 0.34 & $-0.76^{\star \star}$ & & & & & & & \\
\hline & $(0.49)$ & $(0.32)$ & $(0.29)$ & $(0.22)$ & & & & & & & \\
\hline \multirow[t]{2}{*}{ China } & $2.36^{\star \star}$ & $-3.96^{\star \star}$ & 0.33 & 0.24 & & & & & & & \\
\hline & $(0.47)$ & $(0.65)$ & $(0.33)$ & $(0.26)$ & & & & & & & \\
\hline \multirow[t]{2}{*}{ Chile } & 1.26 & 0.86 & -0.72 & $1.72^{\star \star}$ & & & & & & & \\
\hline & $(0.93)$ & $(0.71)$ & $(0.98)$ & $(0.65)$ & & & & & & & \\
\hline \multirow[t]{2}{*}{ ROW } & $-0.79^{\star \star}$ & 0.33 & $0.67^{\star \star}$ & $-1.02^{\star \star}$ & & & & & & & \\
\hline & $(0.28)$ & $(0.22)$ & $(0.26)$ & $(0.27)$ & & & & & & & \\
\hline Expenditure & $1.19^{\star \star}$ & $1.28^{\star *}$ & $0.55^{\star}$ & $0.64^{\star *}$ & & & & & & & \\
\hline$\varepsilon$ & $(0.09)$ & $(0.16)$ & $(0.22)$ & $(0.08)$ & & & & & & & \\
\hline \multicolumn{12}{|l|}{ Pear } \\
\hline \multirow[t]{2}{*}{ China } & & & & & $-1.87^{\star \star}$ & -0.37 & $0.26^{*}$ & $0.43^{\star \star}$ & & & \\
\hline & & & & & $(0.44)$ & $(0.20)$ & $(0.13)$ & $(0.07)$ & & & \\
\hline \multirow[t]{2}{*}{ United States } & & & & & -0.83 & $-0.92^{*}$ & -0.04 & -0.10 & & & \\
\hline & & & & & $(0.44)$ & $(0.40)$ & $(0.25)$ & $(0.11)$ & & & \\
\hline \multirow[t]{2}{*}{ South Africa } & & & & & $0.64^{*}$ & -0.04 & $-1.45^{\star \star}$ & 0.04 & & & \\
\hline & & & & & $(0.32)$ & $(0.29)$ & $(0.13)$ & $(0.08)$ & & & \\
\hline \multirow[t]{2}{*}{ ROW } & & & & & $2.33^{\star \star}$ & -0.23 & 0.10 & $-1.45^{\star \star}$ & & & \\
\hline & & & & & $(0.38)$ & $(0.28)$ & $(0.17)$ & $(0.13)$ & & & \\
\hline Expenditure & & & & & $0.87^{\star *}$ & $1.48^{\star *}$ & $1.54^{\star \star}$ & $0.65^{\star}$ & & & \\
\hline$\varepsilon$ & & & & & $(0.17)$ & $(0.35)$ & $(0.24)$ & $(0.30)$ & & & \\
\hline
\end{tabular}


Table 3. (Continued)

\begin{tabular}{|c|c|c|c|c|c|c|c|c|c|c|c|}
\hline \multirow[b]{2}{*}{ Price } & \multicolumn{4}{|c|}{ Apple } & \multicolumn{4}{|c|}{ Pear } & \multicolumn{3}{|c|}{ Grape } \\
\hline & United States & China & Chile & ROW & China & United States & South Africa & ROW & United States & Australia & ROW \\
\hline \multicolumn{12}{|l|}{ Grape } \\
\hline \multirow[t]{2}{*}{ United States } & & & & & & & & & $1.26^{\star}$ & -0.17 & $-0.42^{\star \star}$ \\
\hline & & & & & & & & & $(0.60)$ & $(0.24)$ & $(0.15)$ \\
\hline \multirow[t]{2}{*}{ Australia } & & & & & & & & & -0.51 & $-1.59^{\star \star}$ & $0.49^{\star}$ \\
\hline & & & & & & & & & $(0.76)$ & $(0.53)$ & $(0.23)$ \\
\hline \multirow[t]{2}{*}{ ROW } & & & & & & & & & $-0.93^{\star \star}$ & $0.34^{*}$ & $-0.65^{\star \star}$ \\
\hline & & & & & & & & & $(0.35)$ & $(0.16)$ & $(0.15)$ \\
\hline Expenditure & & & & & & & & & $0.86^{\star \star}$ & 0.02 & $0.83^{* *}$ \\
\hline$\varepsilon$ & & & & & & & & & $(0.22)$ & $(0.47)$ & $(0.21)$ \\
\hline \multirow[t]{2}{*}{ Apple } & & & & & 1.73 & -2.08 & -2.93 & & -2.75 & 6.63 & \\
\hline & & & & & $(1.47)$ & $(3.04)$ & $(2.11)$ & & $(2.28)$ & (3.99) & \\
\hline \multirow[t]{2}{*}{ Pear } & 1.99 & $-5.11^{\star \star}$ & $-10.93^{*}$ & & & & & & -8.79 & -11.22 & \\
\hline & $(2.13)$ & $(1.91)$ & $(4.47)$ & & & & & & $(4.67)$ & $(8.81)$ & \\
\hline \multirow[t]{2}{*}{ Grape } & -0.60 & $4.73^{\star}$ & 7.72 & & -1.06 & 2.61 & 1.55 & & & & \\
\hline & $(2.10)$ & $(2.02)$ & $(4.43)$ & & $(1.08)$ & $(2.23)$ & $(1.53)$ & & & & \\
\hline \multirow[t]{2}{*}{ Other } & $-0.44^{\star \star}$ & 0.14 & -0.46 & & -0.00 & -0.12 & 0.36 & & -0.24 & -0.45 & \\
\hline & $(0.15)$ & $(0.17)$ & $(0.38)$ & & $(0.17)$ & $(0.35)$ & $(0.24)$ & & $(0.23)$ & $(0.48)$ & \\
\hline
\end{tabular}

Notes: Single and double asterisks $\left({ }^{\star},{ }^{\star \star}\right)$ denote significance at the $5 \%$ and $1 \%$ levels, respectively. See Appendix A for more details. Standard errors are in parentheses. ROW, rest of the world. 
Table 4. Second-order estimation of compensating variation after scenarios of tariff reduction/elimination on Indian fresh apple imports from the United States and all other countries

\begin{tabular}{|c|c|c|c|c|}
\hline \multirow[b]{2}{*}{$\begin{array}{l}\text { Tariff } \\
\text { Cut }\end{array}$} & \multicolumn{2}{|c|}{$\begin{array}{l}\text { Apples Imported from } \\
\text { the United States }\end{array}$} & \multicolumn{2}{|c|}{$\begin{array}{l}\text { Apples Imported from } \\
\text { All Countries }\end{array}$} \\
\hline & $\begin{array}{c}\text { Compensating } \\
\text { Variation } \\
(\%)\end{array}$ & $\begin{array}{l}\text { Equivalent } \\
\text { Value } \\
\text { (million \$) }\end{array}$ & $\begin{array}{c}\text { Compensating } \\
\text { Variation } \\
(\%)\end{array}$ & $\begin{array}{l}\text { Equivalent } \\
\text { Value } \\
\text { (million \$) }\end{array}$ \\
\hline$-10 \%$ & 4 & 8.4 & 8 & 16.8 \\
\hline$-20 \%$ & 9 & 18.9 & 18 & 37.8 \\
\hline$-30 \%$ & 16 & 33.6 & 29 & 60.9 \\
\hline$-40 \%$ & 26 & 54.6 & 41 & 86.1 \\
\hline$-50 \%$ & 40 & 84.0 & 57 & 119.7 \\
\hline
\end{tabular}

Note: The estimated demands are calculated using compensated own-price elasticities and compensated cross-price elasticities, which we calculate in the current article.

exports 'Fuji' apples to India, whereas Chile exports 'Gala' and 'Red Delicious' (Giacinti, 2016). However, the United States competes with China in the fresh apple market; conditional crossprice elasticities between the United States and China are statistically significant. The reason could be those two countries export fresh apples through the entire year, focusing on the first two quarters, whereas Chile exports only in the second and third quarters (Giacinti, 2016). This finding concurs with Luckstead, Devadoss, and Mittelhammer (2014) who found that the United States and China are competitors in ASEAN countries.

Conditional cross-price elasticities between China and South Africa in the fresh pear market are statistically significant and positive, which means that the two countries compete in this market. The reason may be the similar season in which they export to India: Both countries export mostly in March through May (Giacinti, 2016). Conditional cross-price elasticities between the United States and China and between the United States and South Africa are not significant, which indicates that they do not compete in the market; the United States exports pears to India mostly in December through February, whereas China and South Africa export in March through May (Giacinti, 2016). In the fresh grape market, the United States and Australia do not compete with each other.

\subsection{India fresh apple welfare and demand change estimation}

Table 4 presents the tariff effects on Indian consumer welfare. If the $50 \%$ tariff on apples imported from the United States were eliminated, this would lead to a $40 \%$ increase in Indian consumer welfare in the imported fresh apple market, with a value equivalent to $\$ 84$ million in 2015 . That is, Indian consumers can save $\$ 84$ million, to meet the same utility after the tariff cut in the imported apple market. To provide context, considering the 2015 total value of fresh apple Indian imports at \$210 million, \$84 million represented about 40\%. Considering the population of India in 2015 (1.309 billion), this value represented $\$ 0.6$ per capita. A progressive reduction in the import tariff (of 40\%,30\%, 20\%, and 10\%) would lead to subsequent increases in Indian consumer welfare in the imported fresh apple market of $26 \%, 16 \%, 9 \%$, and $4 \%$, respectively. Furthermore, we estimate the effect of a tariff cut on all Indian fresh apple imports. Results are similar. Completely eliminating the $50 \%$ tariff on all apple imports would lead to an increase of consumer welfare of $57 \%$, which is valued at about $\$ 120$ million, or $\$ 0.9$ per capita (Table 4). Similarly, progressive reductions (of $40 \%$, $30 \%, 20 \%$, and $10 \%$ ) in the import tariff would lead to subsequent increases in Indian consumer welfare in the imported fresh apple market of $41 \%, 29 \%, 18 \%$, and $8 \%$, respectively (Table 4 ). These results 
Table 5. Effects of tariff reduction/elimination on Indian demand for all imported fresh apples, imported U.S. fresh apples, and imported Chinese fresh apples

\begin{tabular}{cccc}
\hline Tariff Reduction & $\begin{array}{c}\text { Apple Demand } \\
(\%)\end{array}$ & $\begin{array}{c}\text { U.S. Apple } \\
\text { Demand } \\
(\%)\end{array}$ & $\begin{array}{c}\text { China Apple } \\
\text { Demand } \\
(\%)\end{array}$ \\
\hline$-10 \%$ & 4.9 & 6.7 & -3.2 \\
\hline$-20 \%$ & 9.8 & 13.4 & -6.5 \\
\hline$-30 \%$ & 14.6 & 20.1 & -9.7 \\
\hline$-40 \%$ & 19.5 & 26.7 & -13.0 \\
\hline$-50 \%$ & 24.4 & 33.4 & -16.2 \\
\hline
\end{tabular}

Notes: The estimated demands are calculated using Marshallian own-price elasticities and Marshallian cross-price elasticities which we calculate in the current article. See Appendix B for details.

differ in magnitude from those reported in Devadoss and Wahl (2004) who estimated that a complete tariff elimination in India would increase apple consumption by $12 \%$. Note that in this study we estimate consumer welfare considering the imported fresh apple consumption market, not the general apple consumption volume as Devadoss and Wahl (2004) did. Nonetheless, our findings coincide with Devadoss and Wahl (2004) and Devadoss and Ridley (2014) in that tariffs exert a negative impact on consumers in the country imposing the tariff.

Because real income increases, Indian consumers will consume more imported fresh apples, which are more price elastic compared with other imported fruits. Hence, we analyze demand in the Indian imported apple market without the current $50 \%$ tariff on U.S. imported apples. Table 5 shows the calculated demand for U.S. fresh apples and overall demand for imported fresh apples in India when the $50 \%$ tariff on U.S. apples is eliminated. To calculate changes in demand, we use the Marshallian own- and cross-price elasticities so that income effects are considered. As shown in Table 5, when considering the maximum impact of tariff cuts, Indian consumers demand $33.4 \%$ more U.S. apples and consume 16\% fewer apples from China (the main U.S. competitor). Overall, demand for imported fresh apples would increase by $24 \%$. This coincides with findings by Luckstead, Devadoss, and Mittelhammer (2014) in that tariff elimination would favor U.S. apple producers, and U.S. apple exports would displace Chinese apple exports to India.

\subsection{U.S. fresh apple producers' welfare change estimation}

We include in our analyses the effects of the India tariff elimination on U.S. apple producers. Eliminating import tariffs for fresh apples would lead to a $33.4 \%$ or 77.72 million lb. increase in demand for U.S. apples in India. This increase in demand is about $0.7 \%$ of U.S. total apple production in 2015 , which was $11,027.52$ million $\mathrm{lb}$. To interpret the impact of the demand increases for U.S. apples in India on U.S. producers' welfare, we borrow methods and results from Cassey et al. (2018). In their study, Cassey et al. (2018) estimated a two-stage Muth equilibrium displacement model of the pome (apple) and prunus (peach) markets. A two-stage Muth model is a system of reduced-form equations of the competitive equilibrium of a single-good competitive industry and its associated competitive input markets. We used parameters from Cassey et al. (2018) for the U.S. apple market - the preharvest labor input supply elasticity (3.37), the postharvest labor input supply elasticity (0.73), the elasticity of substitution between inputs (1.1), the preharvest labor input share (0.695), and the postharvest labor input share (0.305) — to come up with an equilibrium price of $\$ 1.24 / \mathrm{lb}$. and quantity demanded of $6,126.5$ million $\mathrm{lb}$. In this study, we estimate the new output quantity for the U.S. apple market, after the $0.7 \%$ demand increase, which 
caused a new equilibrium point leading to a $0.32 \%$ increase in quantity and $0.16 \%$ increase in price. U.S. apple producers are better off after this demand shock. They enjoy $\$ 1,911.4$ million after the demand shock, which is $\$ 12.2$ million higher than before the shock, which was at $\$ 1,899.2$ million. These results agree with findings by Devadoss, Sridharan, and Wahl (2009) and Zahniser, Hertz, and Argoti (2016) in that eliminating tariffs would have a positive effect on the industry sector affected by the tariff in the exporting country.

\section{Summary and conclusions}

Using data on Indian fresh fruits imports between 2000 and 2015, we show the impact of the 50\% tariff imposed by India on U.S. fresh apples imports by applying an RSDAIDS model approach. We use a restricted version of the SDAIDS (source-differentiated almost ideal demand system) because SDAIDS may suffer from a degrees-of-freedom problem in empirical applications. We also tested for price and expenditure endogeneity and tested product aggregation and block separability. All tests support the application of the RSDAIDS model. To estimate welfare effects on Indian consumers, we apply the compensating variation technique. We estimated the restricted SDAIDS model for three major fruits: apples, pears, and grapes. A country is identified as a fresh fruit exporting country if its exports account for at least $10 \%$ of India's total fruit imports.

Using the above-estimated price elasticities for Indian fresh apple imports, we found that India is responsive to U.S. fresh apple imports, suggesting that a $1 \%$ decrease in the price of U.S. apples would increase the quantities demanded by $3.83 \%$. Also, we found that the United States competes with China in the Indian fresh apple market. Indian imports from China are less sensitive to the U.S. price (1.66) than imports from the United States are sensitive to the Chinese price (2.36).

We found that if India eliminates the tariff on imported fresh apples from the United States, Indian consumer welfare would increase by $40 \%$ or $\$ 84$ million ( $\$ 0.6$ per capita) in terms of the 2015 imported fresh apple consumption market. If tariffs to all imported apples were eliminated, Indian consumer welfare in terms of the 2015 imported fresh apple consumption market would increase by $57 \%$ or $\$ 120$ million ( $\$ 0.9$ per capita). Demand for U.S. apples would be expected to increase by $33.4 \%$ if the tariff were eliminated, whereas demand for apples from China-U.S. apple producers' main competitor-would decrease by $16.2 \%$. U.S. apple producers would also be positively affected with gains in welfare equivalent to $\$ 12.2$ million.

Findings in this study add to the evidence that imposing tariffs would have a negative impact on consumers in the country imposing the tariff, evidence that could be used by policy makers when deciding on the imposition or negotiation of tariffs. Our approach based on an RSDAIDS model only considers the effects on consumer demand. Hence, it does not integrate the domestic India fresh apple sector, which is a caveat. It is likely that the effects reported in this study would be different in magnitude if the Indian fresh apple sector were considered. Previous studies (Devadoss and Ridley, 2014) found that the overall impact of imposing tariffs is negative, as the negative effects to consumers outweigh producers' gains and tariff revenues. Additional implications are for fruit exporting companies in the United States, China, and Chile. Tariff elimination would imply a volume increase in Indian apple imports, which would benefit domestic producers in the exporting country.

This study did not consider the possible long-run impacts of tariff elimination. After the consumer price change caused by tariff elimination, the assumption of separability between imported and domestic fruits should be reconsidered because the lower prices of imported fruits might affect consumption of domestic fruits. Also, the price change might affect a range of imported fruit varieties - for example, Indian consumers might want higher-quality apple varieties such as 'Honeycrisp' apples, expanding the market even further.

Financial support. This research received no specific grant from any funding agency or commercial or not-for-profit sectors.

Conflicts of interest. None. 


\section{References}

Ahluwalia, M.S. "Economic Reforms in India since 1991: Has Gradualism Worked?" Journal of Economic Perspectives 16(Summer 2002):67-88.

Alston, J.M., C.A. Carter, R. Green, and D. Pick. "Whither Armington Trade Models?" American Journal of Agricultural Economics 72(May 1990):455-67.

Ananthramiah, S. "A Partial Equilibrium Analysis of NAFTA and Its Impact on U.S. Beef Trade with Canada and Mexico." Ph.D. dissertation, Utah State University, Logan, 1996.

Andayani, R.M., and D.S. Tilley. "Demand and Competition among Supply Sources: The Indonesian Fruit Import Market." Journal of Agricultural and Applied Economics 29(December 1997):279-89.

Barten, A.P. "Maximum Likelihood Estimation of a Complete System of Demand Equations." European Economic Review 1(Autumn 1969):7-73.

Cassey, A., K. Lee, J. Sage, and P.R. Tozer. “Assessing Post-Harvest Labor Shortages, Wages, and Welfare.” Agricultural and Food Economics 6(2018):17.

Deaton, A., and J. Muellbauer. "An Almost Ideal Demand System.” American Economic Review 70(June 1980):312-26.

Devadoss, S., and W. Ridley. "Effects of the Mexican Apple Tariff on the World Apple Market." Review of Development Economics 18(November 2014):763-77.

Devadoss, S., P. Sridharan, and T. Wahl. "Effects of Trade Barriers on U.S. and World Apple Markets." Canadian Journal of Agricultural Economics 57(March 2009):55-73.

Devadoss, S., and T. Wahl. "Welfare Impacts of Indian Apple Trade Policies." Applied Economics 36(December 2004):1289-94.

Dhar, T., J.-P. Chavas, and B.W. Gould. "An Empirical Assessment of Endogeneity Issues in Demand Analysis for Differentiated Products." American Journal of Agricultural Economics 85(August 2003):605-17.

Durand-Morat, A., and E.J. Wailes. "General and Partial Equilibrium Analysis of the Impact of the Central American Agreement on the U.S. Rice Sector." Paper presented at the Annual Meeting of the Agricultural and Applied Economics Association, Providence, Rhode Island, July 24-27, 2005.

Ferreira, G., and A. Perez. Fruit and Tree Nuts Outlook: March 2016. Washington, DC: U.S. Department of Agriculture, Economic Research Service, FTS-361, 2016.

Food and Agriculture Organization of the United Nations. "FAOSTAT: Food Balance Sheets.” Internet site: http://www.fao. org/faostat/en/\#data/FBS (Accessed July 23, 2018).

Friedman, J., and J. Levinsohn. "The Distributional Impacts of Indonesia's Financial Crisis on Household Welfare: A 'Rapid Response' Methodology." World Bank Economic Review 16(December 2002):397-423.

Giacinti, M. Personal Communication. CIF Business Intelligence, September 2016.

Hayes, D.J., T.I. Wahl, and G.W. Williams. “Testing Restrictions on a Model of Japanese Meat Demand.” American Journal of Agricultural Economics 72(August 1990):556-66.

Henneberry, S.R., and S.-H. Hwang. "Meat Demand in South Korea: An Application of the Restricted Source-Differentiated Almost Ideal Demand System Model." Journal of Agricultural and Applied Economics 39(April 2007):47-60.

Index Mundi. "India Fresh Apples Fresh Domestic Consumption by Year." Internet site: https://www.indexmundi.com/ agriculture/?country=in\&commodity=apples\&graph=fresh-domestic-consumption (Accessed April 22, 2018).

India Department of Commerce, Ministry of Commerce and Industry. "Indian Trade Portal." Internet site: http://www. indiantradeportal.in/index.jsp (Accessed July 23, 2018).

Luckstead, J., S. Devadoss, and R.C. Mittelhammer. "Apple Export Competition between the United States and China in the Association of Southeast Asian Nations." Journal of Agricultural and Applied Economics 46(November 2014):635-47.

Mishra, S. 2013 Apple Product Brief: India. Washington, DC: U.S. Department of Agriculture, Foreign Agricultural Service, GAIN Report No. IN3069, 2013.

Naanwaab, C., and O. Yeboah. "The Impact of NAFTA on Agricultural Commodity Trade: A Partial Equilibrium Analysis." Paper presented at the Annual Meeting of the Southern Agricultural Economics Association, Birmingham, Alabama, February 4-7, 2012.

New Zealand, Foreign Affairs and Trade. "New Zealand-India FTA.” Internet site: https://www.mfat.govt.nz/en/trade/freetrade-agreements/agreements-under-negotiation/india/\#negotiations (Accessed July 17, 2018).

Northwest Horticultural Council. "Northwest Horticultural Council: Export Manual—India.” Internet site: http://nwhort. org/export-manual/countries-toc/india/ (Accessed July 26, 2019).

Seale, J.L. Jr., A.L. Sparks, and B.M. Buxton. "A Rotterdam Application to International Trade in Fresh Apples: A Differential Approach.” Journal of Agricultural and Resource Economics 17(July 1992): 138-49.

United Nations. "UN Comtrade [database]." Internet site: https://comtrade.un.org/data (Accessed July 23, 2018).

U.S. Department of Agriculture, Economic Research Service. "Fruit and Tree Nut Yearbook Tables.” Internet site: https:// www.ers.usda.gov/data-products/fruit-and-tree-nut-data/fruit-and-tree-nut-yearbook-tables/ (Accessed July 26, 2019).

U.S. International Trade Commission. Apples: Industry \& Trade Summary. Washington, DC: U.S. International Trade Commission, Office of Industries, Publication ITS-04, 2010.

Weatherspoon, D.D., and J.L. Seale. "Do the Japanese Discriminate against Australian Beef Imports? Evidence from the Differential Approach." Journal of Agricultural and Applied Economics 27(December 1995):536-43. 
The World Bank. "World Bank Open Data.” 2019. Internet site: http://data.worldbank.org/ (Accessed July 26, 2019).

The World Bank. "Population, Total." Internet site: https://data.worldbank.org/indicator/SP.POP.TOTL?locations=IN (Accessed April 22, 2018).

Yang, S.-R., and W.W. Koo. "Japanese Meat Import Demand Estimation with the Source Differentiated AIDS Model." Journal of Agricultural and Resource Economics 19(December 1994):396-408.

Zahniser, S., T. Hertz, and M. Argoti. "Quantifying the Effects of Mexico's Retaliatory Tariffs on Selected U.S. Agricultural Exports.” Applied Economic Perspectives and Policy 38(March 2016):93-112.

\section{Appendix A: Tables of elasticities}

Table A1. Compensated own-price elasticities

\begin{tabular}{|c|c|c|c|c|c|c|}
\hline \multirow[b]{2}{*}{ Apple_US } & \multirow{2}{*}{$\begin{array}{c}\text { Coefficient } \\
-3.048\end{array}$} & \multirow{2}{*}{$\begin{array}{c}\begin{array}{c}\text { Standard } \\
\text { Error }\end{array} \\
0.479\end{array}$} & \multirow{2}{*}{$\frac{z}{-6.360}$} & \multirow{2}{*}{$\frac{P>|z|}{0.000}$} & \multicolumn{2}{|c|}{$\begin{array}{l}\text { [95\% Confidence } \\
\text { Interval] }\end{array}$} \\
\hline & & & & & -3.987 & -2.109 \\
\hline Apple_China & -3.714 & 0.634 & -5.860 & 0.000 & -4.956 & -2.471 \\
\hline Apple_Chile & -0.665 & 0.970 & -0.690 & 0.493 & -2.566 & 1.235 \\
\hline Apple_ROW & -0.875 & 0.263 & -3.330 & 0.001 & -1.390 & -0.361 \\
\hline Pear_China & -1.839 & 0.438 & -4.200 & 0.000 & -2.697 & -0.980 \\
\hline Pear_US & -0.898 & 0.401 & -2.240 & 0.025 & -1.684 & -0.112 \\
\hline Pear_S.Africa & -1.139 & 0.169 & -6.740 & 0.000 & -1.470 & -0.808 \\
\hline Pear_ROW & -1.443 & 0.128 & -11.270 & 0.000 & -1.694 & -1.193 \\
\hline Grape_US & 1.280 & 0.597 & 2.150 & 0.032 & 0.111 & 2.449 \\
\hline Grape_Australia & -1.588 & 0.527 & -3.010 & 0.003 & -2.622 & -0.554 \\
\hline Grape_ROW & -0.636 & 0.153 & -4.160 & 0.000 & -0.936 & -0.336 \\
\hline
\end{tabular}

Note: ROW, rest of the world.

Table A2. Compensated cross-price elasticities between countries of origin

\begin{tabular}{|c|c|c|c|c|c|c|}
\hline Apple & Coefficient & $\begin{array}{c}\text { Standard } \\
\text { Error }\end{array}$ & $z$ & $P>|z|$ & \multicolumn{2}{|c|}{$\begin{array}{c}{[95 \%} \\
\text { Confidence } \\
\text { Interval] }\end{array}$} \\
\hline United States to China & 1.889 & 0.319 & 5.930 & 0.000 & 1.264 & 2.514 \\
\hline United States to Chile & 0.451 & 0.293 & 1.540 & 0.125 & -0.124 & 1.026 \\
\hline United States to ROW & -0.493 & 0.220 & -2.240 & 0.025 & -0.924 & -0.062 \\
\hline China to United States & 2.716 & 0.458 & 5.930 & 0.000 & 1.818 & 3.614 \\
\hline China to Chile & 0.445 & 0.320 & 1.390 & 0.165 & -0.183 & 1.073 \\
\hline China to ROW & 0.529 & 0.255 & 2.070 & 0.038 & 0.029 & 1.029 \\
\hline Chile to United States & 1.412 & 0.919 & 1.540 & 0.125 & -0.390 & 3.213 \\
\hline Chile to China & 0.969 & 0.698 & 1.390 & 0.165 & -0.398 & 2.337 \\
\hline Chile to ROW & 1.848 & 0.648 & 2.850 & 0.004 & 0.579 & 3.118 \\
\hline
\end{tabular}


Table A2. (Continued)

\begin{tabular}{|c|c|c|c|c|c|c|}
\hline \multirow[b]{2}{*}{ ROW to United States } & \multirow{2}{*}{$\begin{array}{c}\text { Coefficient } \\
-0.611\end{array}$} & \multirow{2}{*}{$\begin{array}{c}\begin{array}{c}\text { Standard } \\
\text { Error }\end{array} \\
0.272\end{array}$} & \multirow{2}{*}{$\frac{z}{-2.240}$} & \multirow{2}{*}{$\frac{P>|z|}{0.025}$} & \multicolumn{2}{|c|}{$\begin{array}{c}{[95 \%} \\
\text { Confidence } \\
\text { Interval] }\end{array}$} \\
\hline & & & & & -1.144 & -0.077 \\
\hline ROW to China & 0.456 & 0.220 & 2.070 & 0.038 & 0.025 & 0.886 \\
\hline ROW to Chile & 0.731 & 0.256 & 2.850 & 0.004 & 0.229 & 1.233 \\
\hline \multicolumn{7}{|l|}{ Pear } \\
\hline China to United States & -0.353 & 0.199 & -1.770 & 0.077 & -0.743 & 0.038 \\
\hline China to South Africa & 0.272 & 0.126 & 2.160 & 0.031 & 0.026 & 0.519 \\
\hline China to ROW & 0.436 & 0.071 & 6.130 & 0.000 & 0.297 & 0.576 \\
\hline United States to China & -0.784 & 0.443 & -1.770 & 0.077 & -1.652 & 0.084 \\
\hline $\begin{array}{l}\text { United States to South } \\
\text { Africa }\end{array}$ & -0.019 & 0.253 & -0.070 & 0.942 & -0.515 & 0.478 \\
\hline United States to ROW & -0.093 & 0.115 & -0.810 & 0.418 & -0.318 & 0.132 \\
\hline South Africa to China & 0.687 & 0.318 & 2.160 & 0.031 & 0.064 & 1.309 \\
\hline $\begin{array}{l}\text { South Africa to United } \\
\text { States }\end{array}$ & -0.021 & 0.288 & -0.070 & 0.942 & -0.585 & 0.543 \\
\hline South Africa to ROW & 0.049 & 0.079 & 0.620 & 0.534 & -0.106 & 0.205 \\
\hline \multicolumn{7}{|l|}{ Grape } \\
\hline United States to Australia & -0.161 & 0.241 & -0.670 & 0.504 & -0.634 & 0.311 \\
\hline United States to ROW & -0.406 & 0.154 & -2.630 & 0.009 & -0.708 & -0.103 \\
\hline Australia to United States & -0.510 & 0.762 & -0.670 & 0.504 & -2.003 & 0.984 \\
\hline Australia to ROW & 0.486 & 0.233 & 2.080 & 0.037 & 0.028 & 0.943 \\
\hline
\end{tabular}

Note: ROW, rest of the world.

\section{Appendix B: Indian fresh apple welfare change and demand estimation}

In this section, we describe the model used to obtain the demand estimation of Indian fresh apple imports as price changes. To consider the impacts of the price increases on household welfare, we follow Friedman and Levinsohn (2002). We start with a minimum expenditure function, $E(u, p)$, given price $p$ and utility level $u$. Because the partial derivative of the minimum expenditure function with respect to price is quantity consumed, we get

$$
\Delta E=q \Delta p .
$$

Then we obtain the following expression with a second Taylor expansion of $\Delta E=q \Delta p$ :

$$
\Delta E \approx q \Delta p+\frac{1}{2} \Delta p s \Delta p
$$

where $q$ is quantity; $\Delta p$ is price change; and $s=\frac{\partial q^{c}}{\partial p}$, which is the compensated derivatives of demand, where $q^{c}$ is the compensated demand function. In terms of budget shares, we get

$$
\Delta \ln E \approx \sum_{h} w_{i_{h}} \Delta \ln p_{i_{h}}+\frac{1}{2} \sum_{h} \sum_{k} E_{i_{h} i_{k}} \Delta \ln p_{i_{h}} \Delta \ln p_{i_{k}},
$$

where $E_{i_{h} i_{k}}=p_{i_{h}} s_{i_{h} i_{k}} p_{i k} / E ; s_{i_{h} i_{k}}$ is the Slutsky derivatives. Then we obtain the following equation:

$$
\Delta \ln E \approx \sum_{h} w_{i_{h}} \Delta \ln p_{i_{h}}+\frac{1}{2} \sum_{h} \sum_{k} w_{i_{h}} \varepsilon_{i_{h} i_{k}} \Delta \ln p_{i_{h}} \Delta \ln p_{i_{k}},
$$

where the compensated price elasticity $\varepsilon_{i_{h} i_{k}}=-1+\frac{\gamma_{i_{h k}}}{w_{i_{h}}}+w_{i_{k}}$ when $h=k ; \varepsilon_{i_{h} i_{k}}=\frac{\gamma_{i_{h k}}}{w_{i_{h}}}-w_{i_{k}}$ when $h \neq k$. 
Now we derive how we compute demand changes in the imported fresh apple market in India:

$$
E=\sum_{i} X_{i} P_{i},
$$

where $E$ is Indian expenditures on imported fresh apples, $X$ is imports, and $i$ is import sources.

Taking the derivatives of $E$ with respect to $P_{1}$, we have

$$
\frac{\partial E}{\partial P_{1}}=X_{1}+\frac{\partial X_{1}}{\partial P_{1}} P_{1}+\frac{\partial X_{2}}{\partial P_{1}} P_{2}+\ldots+\frac{\partial X_{n}}{\partial P_{1}} P_{n} .
$$

Utilizing $\frac{P_{n}}{P_{n}}$ and $\frac{X_{n}}{X_{n}}$ to manipulate equation (B-6), then multiplying by $\frac{P_{1}}{Y}$, we get

$$
\frac{\partial E / E}{\partial P_{1} / P_{1}}=w_{1}\left(\varepsilon_{11}+1\right)+w_{2} \varepsilon_{21}+\ldots+w_{n} \varepsilon_{n 1},
$$

where $\frac{\partial E / E}{\partial P_{1} / P_{1}}$ represents percentage change in expenditure in terms of a price change of good $1 ; w\left(\varepsilon_{11}+1\right)$ is a portion of a demand change for good $1 ; W_{n} \varepsilon_{n 1}$ is a portion of a demand change for good $n ; w_{n}$ is the consumption share of $n$ 's fresh apples; $\varepsilon_{n 1}$ is the Marshallian own-price elasticity when $n=1$ or cross-price elasticity when $n \neq 1$. For calculating percentage change in expenditure in terms of a price change of U.S. apples,

$$
\begin{aligned}
\frac{\partial E / E}{\partial P_{\text {U.S.apple }} / P_{U . S . a p p l e}}= & w_{\text {U.S.apple }}\left(\varepsilon_{\text {U.S.apple }}+1\right)+w_{\text {Chinese apple }} \varepsilon_{\text {Chineses apple, U.S.apple }}+w_{\text {Chilian apple }} \varepsilon_{\text {Chilian apple, U.S.apple }} \\
& +w_{\text {Other apple }} \varepsilon_{\text {Other apple U.S.apple }} .
\end{aligned}
$$

\section{Appendix C: Derivations of elasticities}

In this section, we derive price and expenditure elasticities. A definition of the uncompensated price elasticities of demand is

$$
\varepsilon_{i j}=\frac{d \ln q_{i}}{d \ln p_{j}},
$$

where $q_{i}$ represents the quantities demanded of fruit $i$, and $p$ denotes the price for fruit $j$. In terms of RSDAIDS, we use Stone's price index $\ln P=\sum_{i} \sum_{h} w_{i_{h}} \ln p_{i_{h}}$ and equation (6) in the main text. Then we derive

$$
\frac{d \ln q_{i}}{d \ln p_{j}}=-\delta_{i j}+\frac{d \ln w_{i}}{d \ln p_{j}}=-\delta_{i j}+\frac{\gamma_{i j}}{w_{i}}-\frac{\beta_{i}}{w_{i}} \frac{d \ln P}{d \ln p_{j}},
$$

where $\delta_{i j}$ is the Kronecker delta $\left(\delta_{i j}=0\right.$ for $i=j ; \delta_{i j}=1$ for $\left.i \neq j\right)$, and $P$ is Stone's price index. Then own-price elasticity is

$$
\varepsilon_{i_{h} i_{h}}=-\delta_{i_{h} i_{h}}+\frac{\gamma_{i_{h h}}}{w_{i_{h}}}-\frac{\beta_{i_{h}}}{w_{i_{h}}} \frac{d \ln P}{d \ln p_{i_{h}}}=-1+\frac{\gamma_{i_{h h}}}{w_{i_{h}}}-\beta_{i_{h}} .
$$

Cross-price elasticities between the same goods from different sources are

$$
\varepsilon_{i_{h} i_{k}}=-\delta_{i_{h} i_{k}}+\frac{\gamma_{i_{h k}}}{w_{i_{h}}}-\frac{\beta_{i_{h}}}{w_{i_{h}}} \frac{d \ln P}{d \ln p_{i_{k}}}=\frac{\gamma_{i_{h k}}}{w_{i_{h}}}-\beta_{i_{h}} \frac{w_{i_{k}}}{w_{i_{h}}} .
$$

Cross-price elasticities between different goods (i.e., the cross-price elasticity between fruit $i$ imported from country $h$ and fruit $j$ imported from the rest of the world) are

$$
\varepsilon_{i_{h} j}=-\delta_{i_{h} j}+\frac{\gamma_{i_{h} j}}{w_{i_{h}}}-\frac{\beta_{i_{h}}}{w_{i_{h}}} \frac{d \ln P}{d \ln p_{j}}=\frac{\gamma_{i_{h} j}}{w_{i_{h}}}-\beta_{i_{h}} \frac{w_{j}}{w_{i_{h}}} .
$$

Expenditure elasticities are

$$
\varepsilon_{i_{h}}=\frac{d \ln q_{i_{h}}}{d \ln E}=1+\frac{\beta_{i_{h}}}{w_{i_{h}}} .
$$

Cite this article: Lee K, Gallardo RK, and Giacinti M (2020). The Indian Demand for Imported Fresh Apples: Effects of Tariff Reductions. Journal of Agricultural and Applied Economics 52, 30-46. https://doi.org/10.1017/aae.2019.32 